Louisiana State University

LSU Digital Commons

Faculty Publications

Department of Biological Sciences

5-7-2013

\title{
Lead uptake in diverse plant families: A study applying X-ray absorption near edge spectroscopy
}

\author{
Gudrun L. Bovenkamp \\ Universität Bonn \\ Alexander Prange \\ Hochschule Niederrhein \\ Wolfgang Schumacher \\ Universität Bonn \\ Kyungmin Ham \\ Louisiana State University \\ Aaron P. Smith \\ Louisiana State University
}

See next page for additional authors

Follow this and additional works at: https://digitalcommons.Isu.edu/biosci_pubs

\section{Recommended Citation}

Bovenkamp, G., Prange, A., Schumacher, W., Ham, K., Smith, A., \& Hormes, J. (2013). Lead uptake in diverse plant families: A study applying $\mathrm{X}$-ray absorption near edge spectroscopy. Environmental Science and Technology, 47 (9), 4375-4382. https://doi.org/10.1021/es302408m 
Authors

Gudrun L. Bovenkamp, Alexander Prange, Wolfgang Schumacher, Kyungmin Ham, Aaron P. Smith, and Josef Hormes 


\title{
Lead Uptake in Diverse Plant Families: A Study Applying X-ray Absorption Near Edge Spectroscopy
}

\author{
Gudrun L. Bovenkamp, ${ }^{* \dagger, \S}$ Alexander Prange, ${ }^{\ddagger, \S, \nabla}$ Wolfgang Schumacher, ${ }^{\perp}$ Kyungmin Ham, ${ }^{\S}$
} Aaron P. Smith, ${ }^{\#}$ and Josef Hormes ${ }^{\dagger, \S, \|}$

\author{
${ }^{\dagger}$ Institute of Physics, University of Bonn, Nussallee 12, 53115 Bonn, Germany \\ ${ }^{\ddagger}$ Section Microbiology and Food Hygiene, Niederrhein University of Applied Sciences, Rheydter Straße 277, 41065 \\ Mönchengladbach, Germany \\ ${ }^{\S}$ Center for Advanced Microstructures and Devices (CAMD), Louisiana State University, 6980 Jefferson Hwy, Baton Rouge, \\ Louisiana 70806, United States \\ "Canadian Light Source (CLS), University of Saskatchewan, 44 Innovation Blvd., Saskatoon, SK S7N 2V3, Canada \\ ${ }^{\perp}$ Institute of Crop Science and Resource Conservation (INRES), Department: Ecology of Cultural Landscape - Geobotany and \\ Nature Conservation, University of Bonn, Karlrobert-Kreiten-Straße13, 53115 Bonn, Germany \\ \#Department of Biological Sciences, Louisiana State University, Baton Rouge, Louisiana 70803, United States

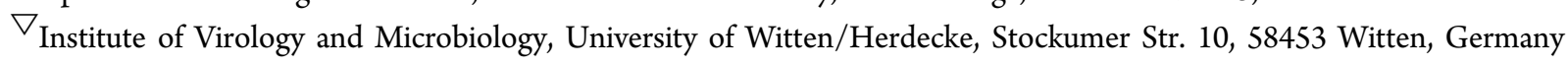

\section{Supporting Information}

\begin{abstract}
The chemical environment of lead in roots and leaves of plants from four different plant families and a lichen from a former lead mining site in the Eifel Mountains in Germany was determined by $\mathrm{Pb}_{3}$-edge XANES measurements using solid reference compounds and also aqueous solutions of different ionic strength simulating the plant environment. $\mathrm{Pb}^{2+}$ ions in the plants were found to have two major coordinations, one with nine oxygen atoms in the first coordination shell similar to outer-sphere complexation and a second coordination with just three oxygen atoms similar to inner-sphere complexation. This can be interpreted assuming that lead is sorbed on the surface of cell walls depending on the concentration of lead in the soil solution. Pb $\mathrm{L}_{3}$-edge $\mathrm{XANES}$ spectra of dried and fresh plant samples are very similar because sorption does not change with removal of water but only because of the initial ionic strength. No bonding to biologically important groups $(-\mathrm{S},-\mathrm{N})$ or precipitation $\left(-\mathrm{PO}_{4}\right)$ was found.

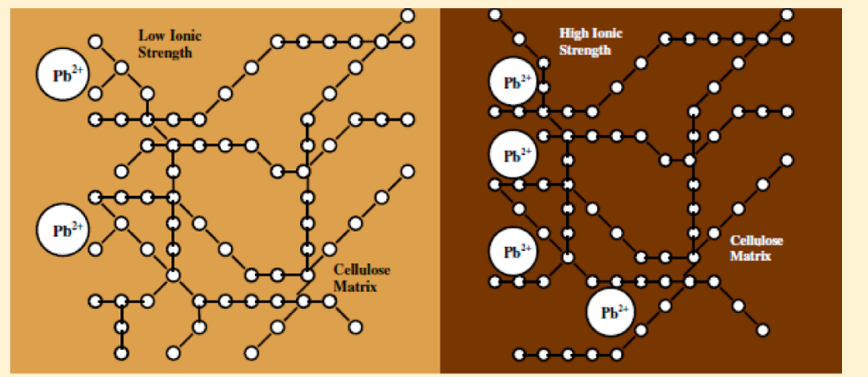

\section{INTRODUCTION}

Lead, as one of the seven metals of antiquity, remains a very important metal in global economics because of its wide applicability, but it can also be a potent toxin to biological systems. ${ }^{1}$ A technique for the remediation of heavy metalcontaminated sites that is of great interest because of its ecological advantages is phytoremediation. ${ }^{2}$ To enhance phytoremediation technologies, the type of the actual bonding and the location of storage is crucial information. The processes and mechanisms of uptake and storage are described by Clemens and co-workers ${ }^{3}$ as understood so far. Binding complexes can be simplified to $\mathrm{PO}_{4}{ }^{3-}-, \mathrm{COO}^{-}-, \mathrm{NO}_{3}{ }^{-}-$, $\mathrm{N}^{-}-$, and $\mathrm{S}^{-}-$groups. In a recent review, Peralta-Videa and coworkers ${ }^{4}$ point out that lead is first adsorbed to the root surface outside the roots and then bound in the form of phosphate or carbonate inside the plants on various surfaces because precipitation is most likely for lead compounds.

The objective of this study was to determine the lead speciation in plants from a naturally lead-contaminated environment using X-ray absorption near edge structure (XANES) spectroscopy. Because of geological characteristics of the area at Keldenich-Kall in the Eifel Mountains, Germany, extended lead deposits are very close to the surface. Detailed descriptions of the area, and the vegetation are given by Schumacher ${ }^{5}$ and Brown. ${ }^{6}$ For this study we used Ameria maritima, Silene vulgaris, Festuca ovina, and Avena pratensis, and the lichen Cladonia portentosa (cf. Supporting Information (SI) Figures S5-S9). In order to get additional local information about the lead uptake in these plants, element-specific X-ray tomography experiments were performed.

XANES as an in situ technique is used quite often to study the chemical environment, for example, of heavy metals in plants. ${ }^{7}$ Since the XANES spectrum is a unique representation

Received: June 14, 2012

Revised: January 14, 2013

Accepted: March 21, 2013

Published: March 21, 2013 
of the chemical environment of the element under investigation the standard procedure for the analysis of XANES spectra is the fingerprinting method: the spectrum of the unknown sample is compared to a variety of spectra from suitable references. Among the reports using XANES to investigate the lead environment in plants, living plants (such as wheat) as well as $\mathrm{Pb}$-impregnated dried biomaterials (such as dried alfalfa biomass) were investigated. ${ }^{8-17}$ All groups mostly used solid powder reference compounds (e.g., $\mathrm{PbO}, \mathrm{PbS}, \mathrm{Pb}(\mathrm{II})$ acetate) for their analyses and the majority of these groups report that lead has an oxygen environment, presumably $\mathrm{COOH}$, as in acetate. Sharma and co-workers ${ }^{10}$ and Tian and co-workers ${ }^{12}$ additionally report a $\mathrm{Pb}$ sulfur environment. Cotter-Howells and co-workers ${ }^{11}$ used chloropyromorphite $\left(\mathrm{Pb}_{5}\left(\mathrm{PO}_{4}\right)_{3} \mathrm{Cl}\right)$ within their set of reference compounds and reported precipitation as in chloropyromorphite. A review of the literature regarding investigations of the chemical environment of lead in plants clearly shows that the results are still quite controversial. It is likely that assumptions based on available reference compounds, or the lack thereof, often directed the conclusions. In this study we used on the one hand a broad variety of organic and inorganic lead reference compounds as powders as were used in previous studies, and on the other hand, since all living systems are dependent on water-based environments, we applied an intensive, additional approach: simulating the plant environment by using several aqueous lead solutions with and without complexing agents as reference compounds. $\mathrm{Pb}(\mathrm{II})$ compounds have a rich coordination chemistry and a complex behavior in solutions. $1,18,19$ Adsorption studies of lead on different minerals were previously investigated with XANES spectroscopy by Rouff and coworkers $^{18}$ as well as Strawn and Sparks. ${ }^{19}$ Their experiments, changing ionic strength and $\mathrm{pH}$ of the sorption solutions, show that adsorption of inner- and outer-sphere complexes of lead depends on $\mathrm{pH}$ and ionic strength of the solution. ${ }^{18}$

Additional aims of this study were (a) to determine how sensitive $\mathrm{Pb} \mathrm{L}_{3}$-XANES spectra of biological systems are to the specifics of second and higher coordinations shells, that is, which reference compounds are suitable and required for analyzing the spectra of lead in plants, and (b) to investigate the sensitivity limit of the linear combination fitting process that is used as a fingerprint method for analyzing the $\mathrm{Pb} \mathrm{L}_{3}$-XANES spectra of "unknown" samples.

\section{MATERIALS AND METHODS}

Plant Preparation. In two series of experiments first dried plant samples and second fresh plant samples were used. For the first series of measurements, whole plants of Silene vulgaris, Ameria maritima, Festuca ovina, and Avena pratensis and the lichen Cladonia portentosa together with soil were collected at the meadow on the Tanzberg near Kall/Keldenich, Eifel Mountains, Germany in winter 2006/2007. These plants were washed carefully with tap water to remove soil and dust, and leaves (in the case of $S$. vulgaris stems were used instead of leaves because during the winter season leaves dried and had already senesced) and roots were separated. It was not necessary to cut the lichen because they have no roots. The samples were dried in a furnace at $100{ }^{\circ} \mathrm{C}$ for several hours. For XANES measurements, the dried plant parts were ground in an agate mortar, sieved to get particles smaller than $100 \mu \mathrm{m}$ (not for $A$. pratensis samples because they could not be ground), pressed to pellets, and mounted onto adhesive Kapton tape.
For the second series of measurements, whole plants Silene vulgaris, Ameria maritima, Festuca ovina, and Avena pratensis together with soil were collected from the same area in the Eifel Mountains in summer 2008 and 2009. These plants were replanted in plastic pots together with collected soil to be taken to the synchrotron facility. To keep the plants alive they were watered with tap water. For measurements, select parts of the plants (leaf, stem, or root) were cut and washed carefully with tap water. The plant parts were not dried prior to XANES measurements but several leaves or $1 \mathrm{~cm}$ root cuttings were directly mounted on adhesive Kapton tape right before the measurements.

Solutions and Other Reference Compounds. All reference compounds and properties are listed in SI Table S1. The inorganic powder compounds were purchased from Sigma Aldrich and Alfa Aesar in high purity. Chloropyromorphite was synthesized by a modification of the method reported by Cotter-Howell and co-workers. ${ }^{11}$ The white powder was dried for $24 \mathrm{~h}$ at $20{ }^{\circ} \mathrm{C}$. The purity and structure of this compound were verified by X-ray powder diffraction. All solutions were prepared with deionized (Millipore) water of $\mathrm{pH}$ 7.4. The solution with high concentration was a $0.15 \mathrm{M}$ lead nitrate solution $(I=0.15 \mathrm{M}, \mathrm{pH} 3.4)$. The solution with low lead concentration was a $1.5 \mathrm{mM}$ lead nitrate solution $(I=1.5$ $\mathrm{mM}, \mathrm{pH}$ 5.5). These solutions contain mostly (about 99\%) $\mathrm{Pb}^{2+}(\mathrm{aq}) .{ }^{19}$ Another solution that contained primarily (about $70 \%)$ the hydrolysis complex $\mathrm{Pb}_{4}(\mathrm{OH})_{4}{ }^{4+}(\mathrm{aq})$ was prepared using lead methyl mercaptide) as a $0.16 \mathrm{M}$ solution $(I=0.16$ $\mathrm{M}, \mathrm{pH} 8){ }^{19}$ The water for this solution was degassed by bubbling argon gas while stirring for $30 \mathrm{~min}$. The speciation for this solution based on the hydrolysis constants given by Baer and Mesmer $^{20}$ are likely to be $70 \% \mathrm{~Pb}_{4}(\mathrm{OH})_{4}{ }^{4+}(\mathrm{aq}), 19 \% \mathrm{~Pb}^{2+}$ (aq), $9 \% \mathrm{~Pb}_{3}(\mathrm{OH})_{8}{ }^{4+}(\mathrm{aq})$, and $1.9 \%$ other $\mathrm{Pb}-\mathrm{OH}$ complexes. For XANES measurements, $50 \mu \mathrm{L}$ of the solution was dropped onto a $0.5 \mathrm{~cm}^{2}$ sized piece of filter paper which was enclosed in Kapton tape.

ICP-AES and AAS Analysis (Inductively Coupled Plasma Atomic Emission and Absorption Spectroscopy). Absolute concentrations of lead in dried plants (leaves and roots) of the winter season were determined by the Dr. Boehling Laboratory of Analytical Chemistry, Bonn, Germany using standard AES and AAS-methods. ${ }^{21}$

X-ray Tomography. X-ray tomography was performed at the X-ray tomography beamline at CAMD, Baton Rouge, LA, for a $1 \mathrm{~cm}$ long piece of $S$. vulgaris root. The X-ray tomography beamline is equipped with a multilayer monochromator (W$\mathrm{B}_{4} \mathrm{C}$ ), providing X-rays from 8 to $40 \mathrm{keV}$ with $\Delta E / E=1-3 \%$. Transmitted X-rays are converted to visible light with a synthetic garnet (Ce:YAG) scintillator. The scintillator is imaged onto a Princeton Instrument Pixis CCD camera, 2048 $\times 512$ pixels, each $13.5 \times 13.5 \mu \mathrm{m}^{2}$, with a $5.4 \times$ microscope objective. The sample is mounted with clay atop a rotational stage. Data are collected at $0.25^{\circ}$ increments from $0^{\circ}$ to $180^{\circ}$. The double correlation method is used to reduce artifacts. Each CCD image was converted to a transmission image with flat field (i.e., without the sample) and average dark field (i.e., background) corrections. Flat field images were collected at intervals of 30 CCD images. Sinograms (projection vs angle) were constructed, and the transmission values were converted to a line integral of the absorption. The slice reconstruction was done with Inverse Radon Transform in MatLab, and the slices were assembled into a single reconstructed volume, each volume element containing the value of the voxel linear 
attenuation coefficient (a 3-dimensional minimal box, similar to a pixel for 2 dimensions). The voxel linear attenuation coefficients were corrected by rescaling such that projections of representative slices yield voxel linear attenuation coefficients in agreement with the original absorption images. The experiment was performed at 12.5 and $13.5 \mathrm{keV}$, below and above $\mathrm{Pb} \mathrm{\textrm {L } _ { 3 }}$-edge, at different heights. Visualization was performed by the program ImageJ. Further information and details can be found in the literature. ${ }^{22-24}$

XANES-Spectroscopy. The XANES experiments were carried out at the INE beamline of the synchrotron radiation source ANKA, Karlsruhe, Germany, with an electron energy of $2.4 \mathrm{GeV}$ using either $\mathrm{Si}(311)$ crystals for the double-crystalmonochromator (DCM) or $2.5 \mathrm{GeV}$ using $\mathrm{Ge}(422)$ crystals. Spectra of the same compounds measured with both crystal pairs showed that there are small differences due to the different energy resolution of the crystals. These differences are below the measurement uncertainty for $\mathrm{Pb} \mathrm{L}_{3}$-XANES spectra which will be discussed below. Thus, the XANES spectra measured under these different conditions, but at the same beamline, qualify for direct comparison. For calibration, the energy of the $\mathrm{Pb} \mathrm{L}_{3}$-edge was set to $13035 \mathrm{eV}$ using the first maximum of the first derivative of the metal foil spectrum. XANES spectra were measured with 5 and $1 \mathrm{eV}$ equidistant energy steps in the pre-edge region of $12885-12985 \mathrm{eV}$ and 12 985-13005 eV, respectively, with $0.5 \mathrm{eV}$ equidistant energy steps in the edge region of $13005-13085 \mathrm{eV}$ and with equidistant $\mathrm{k}$ steps of $0.03 \AA^{-1}$ in the postedge region of 13 085-13 $275 \mathrm{eV}$. Data were normalized using a second-order spline for pre- and postedge regions and analyzed using the ATHENA program of the IFFEFIT package. ${ }^{25}$

The plants of the winter collection, the powder reference compounds, and the solutions were measured in transmission mode using ion chambers filled with argon at ambient pressure. The plants of the summer collection were measured in fluorescence mode using a Canberra 5-element Germanium semiconductor detector. A total of $10-20 \mathrm{mg}$ of each powdered compound was mixed with approximately 50-70 $\mathrm{mg}$ of cellulose, pressed to a pellet and mounted on adhesive Kapton tape. Measurements of transmission samples were repeated at least twice for reproducibility. Measurements of fluorescence samples were repeated up to 6 times and averaged to enhance the signal-to-noise ratio. All measurements were performed with the samples under ambient air pressure and room temperature conditions.

\section{RESULTS}

ICP-AES and AAS Analysis. To determine the concentration and distribution of $\mathrm{Pb}$ in the various plant species, ICP/ AES analyses were carried out on the roots and leaves (or stems, in the case for S. vulgaris). As shown in SI Table S2, Pb was detected in all samples, showing the capability of all the plants examined to take up $\mathrm{Pb}$ in some quantity into roots and onto above ground tissues. For each species, the $\mathrm{Pb}$ concentration was higher in roots than in shoot tissues, supporting previous studies. ${ }^{9,10,13,26-28}$ In addition, the $\mathrm{Pb}$ concentrations in the roots are slightly higher for S. vulgaris and A. maritima compared to F. ovina, but significantly higher than for to A. pratensis. This correlates with the observation that areas with high $\mathrm{Pb}$ concentrations predominately host $S$. vulgaris, A. maritima, and F. ovina, whereas A. pratensis predominates in soils with relatively low $\mathrm{Pb}$ levels. ${ }^{29}$ Differences in the root-to-shoot ratio of $\mathrm{Pb}$ among the plant species suggest that they have different mechanisms for transporting or tolerating $\mathrm{Pb}$.

Sensitivity and Detection Limit of $\mathrm{Pb} \quad \mathrm{L}_{3}$-XANES Spectra. XANES spectra are sensitive to the types of neighboring atoms around the absorbing atom and their geometry (e.g., bond distances, bond angles, and coordination numbers). That is why XANES spectra can be considered a fingerprint of the chemical environment. Bargar and coworkers $^{30}$ reported that $\mathrm{Pb} \mathrm{L}_{3}$-XANES spectra are sensitive to the structure of the first coordination shell (i.e., element and/or coordination number). Figure 1, showing a selection of $\mathrm{Pb} \mathrm{L}_{3}$ -

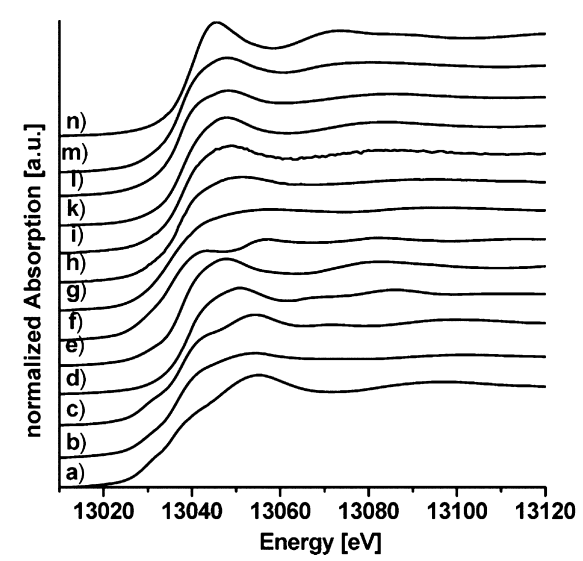

Figure 1. Selected $\mathrm{Pb} \mathrm{L}_{3}$-XANES spectra of the references used in the LC fitting: (a) phthalocyanine lead, (b) lead silicate, (c) lead(II) oxide, (d) chloropyromorphite lead, (e) lead chromate, (f) lead metal (foil), (g) hexadecyl lead mercaptide, (h) $\mathrm{Pb}_{4}(\mathrm{OH})_{4}{ }^{4+}$ (aq) (high ionic strength, high $\mathrm{pH}$ (8.0), (i) $\mathrm{Pb}^{2+}(\mathrm{aq})$ (low ionic strength, high $\mathrm{pH}$ (5.5)), (k) $\mathrm{Pb}^{2+}(\mathrm{aq})$ (high ionic strength, low $\mathrm{pH}$ (3.4)), (1) lead citrate tri hydrate, $(\mathrm{m})$ lead carbonate, $(\mathrm{n})$ lead nitrate. The spectra are shifted for clarity. (a) $-(\mathrm{g})$ and $(\mathrm{l})-(\mathrm{n})$ are powder compounds.

XANES spectra, demonstrates a lack of detailed fine structure compared, for example, to transition metal K-edges. Additional spectra are shown in SI Figure S1. In a previous study we presented a method ( $\triangle \mathrm{RMS}$ method) to estimate the sensitivity of $\mathrm{Pb} \mathrm{L}_{3}$-XANES spectra with regard to the local atomic structure (LAS) around $\mathrm{Pb} .^{31}$ For that study we defined the difference of XANES spectra as $\triangle \mathrm{RMS}=$ square root of the difference of two spectra. The level of uncertainty was determined as $\Delta \mathrm{RMS} \leq 0.01$ for $\mathrm{Pb}_{3}$-edge. This value includes differences between transmission samples including significant changes in sample preparation. For the comparison of transmission and fluorescence samples (including noise levels) a new level of uncertainty was determined to $\triangle \mathrm{RMS} \leq$ 0.017. $\mathrm{Pb} \mathrm{L}_{3}$-XANES spectra were shown to still be significantly different when the chemical environment around the absorber differs in the first three coordination shells. This means that through a direct comparison of suitable $\mathrm{Pb} \mathrm{L}_{3}$-XANES spectra the local atomic environment can be determined up to the third coordination shell. In most biological samples, the element of interest is present in more than one chemical environment. In these cases a linear combination fitting (LCF) process with XANES spectra of several references is used for analyzing the corresponding sample spectrum. For the following discussion we define the detection limit for minor compounds in LCF of $\mathrm{Pb} \mathrm{L}_{3}$-XANES as the fraction (in \%) below that the exchange of any minor compound for another one does not enhance the quality of the fit. 
To estimate this detection limit, two samples with known composition of two lead powder compounds each were prepared, measured and LC fitting of $\mathrm{Pb} \mathrm{L}_{3}$-XANES using 24 references (powder as well as solution samples) was performed where all possible combinations for two compounds were calculated using the ATHENA program (not shown). The powder compounds lead citrate trihydrate and lead hexadecyl mercaptide were mixed in ratios of $65 \%$ to $35 \%$ and $90 \%$ to $10 \%$ respectively. Using this combinational method where the program selects 2 out of 24 references to fit the unknown sample results in a list of fits. To determine which of these fits correctly reconstructed the unknown sample the $\chi^{2}$ value (correctly: we used $\chi_{\mathrm{n}}^{2}=\chi^{2} / n$, where $n$ is the number of points used for the fit) is used. For more details see Kelly and coworkers. $^{32}$ This $\chi^{2}$ value gives the relative quality of the LC fit. It cannot give absolute quality, but can only be compared to the $\chi^{2}$ values of the other fits. Differences in the $\chi^{2}$ value are only significant if the ratio $\chi_{i}^{2} / \chi_{\text {ref }}^{2}>2$ where $\chi_{i}^{2}$ is the $\chi^{2}$ value of the LC fit with number $i$ and $\chi_{\text {ref }}^{2}$ is the $\chi^{2}$ value of the best LC fit in the list. We call ratios with $\chi_{i}^{2} / \chi_{\text {ref }}^{2} \leq 2$ : same level of quality for the LC fits. For the first of the known mixtures $(65 / 35)$ the LC fitting procedure for $\mathrm{Pb} \mathrm{L}_{3}$-XANES spectra with 2 references out of 24 using the combination lead citrate tri hydrate/hexadecyl lead mercaptide for the fit resulted not only in the best LC fit of the list of fits but it also could reproduce the mixture $(65 \%$ lead citrate tri hydrate/35\% hexadecyl lead mercaptide) with significantly better $\chi^{2}$-value compared to any other combination. For the second mixture (90\% lead citrate trihydrate $/ 10 \%$ hexadecyl lead mercaptide) the correct combination (lead citrate tri hydrate and hexadecyl lead mercaptide) was not calculated to be the best LC fit of the list for this sample but was only likely within the same level of quality as several other fits. Hence, we estimate the detection limit for minor compounds in LCF of $\mathrm{Pb} \mathrm{L}_{3}$-XANES to be between $10 \%$ and $30 \%$. Below this value a compound that might contribute to the unknown spectrum cannot be identified with certainty but can be used alternatively. Above $30 \%$ a minor compound can be detected with certainty. Using this method limited our LC fits to 2 compounds to understand the lead distribution in plant samples.

Certain reference compounds were found to be not distinguishable by their $\mathrm{Pb} \mathrm{L}_{3}$-XANES spectra because their $\triangle$ RMS value is below or equal to the level of uncertainty of 0.01 . This is the case for lead citrate tri hydrate compared to $\mathrm{Pb}^{2+}$ (aq) with low ionic strength and $\mathrm{pH}$ 5.5. The LCF procedure showed that the correct fractions for both mixtures were determined for a fit using $\mathrm{Pb}^{2+}$ (aq) with low ionic strength and $\mathrm{pH} 5.5$ instead of lead citrate tri hydrate, however, in both cases with lower $\chi^{2}$-value. These two cases show that if the correct reference compound is not available but a compound with a very similar chemical coordination the spectrum of an unknown sample can still be correctly fitted. This means that reference compounds with $\mathrm{Pb} \mathrm{L}_{3}$-XANES spectra that cannot be distinguished using the $\triangle \mathrm{RMS}$ method bring redundant information into the combinational LCF list, that is, LC fits with very similar fractions but reference compounds with slightly different LAS. In order to shorten the LC fitting time, only one of these reference compounds that can be called linear dependent should be used. Therefore, lead citrate trihydrate was not used which reduced the number of references to 23. For the same reason the results of extended solution experiments using lead nitrate solutions with citric acid, cellulose, or cysteine, and solutions with lead acetate, are not presented here in detail. These spectra do not have to be included in the LCF procedure because these solution reference compounds have spectra that are not distinugishable from spectra of other reference compounds. The reason for this low sensitivity of the LCF of the $\mathrm{Pb} \mathrm{L}_{3}$-XANES spectra in general is their extreme similarity. Because most of the compounds used for $\mathrm{LCF}$ are $\mathrm{Pb}$ (II) compounds which have only a small edge shift with regard to each other and a more diffuse fine structure compared to K-edge XANES spectra of transition metals like iron. $^{33}$

Appropriate $\mathrm{Pb}$ Reference Compounds for Plant Studies. The observations discussed in the previous paragraph demonstrate that using the fingerprints of XANES spectra (for $\mathrm{Pb}$ L3-edge specifically) the LAS can be determined only up to the third coordination shell (e.g., lead citrate tri hydrate and $\mathrm{Pb}^{2+}$ (aq) low ionic strength and $\mathrm{pH}$ 5.5). Therefore, the selection of reasonable and suitable references is limited. In biological processes proteins play a major role, but these big molecules cannot be distinguished as a whole molecule when they have the same basic chemical structure for two or three shells around the atom of interest, even though they have a different shape and function in general. A wide spectrum of inorganic and organic solid lead compounds is commercially available, but not all of them are suitable as references for lead in a biological environment.

In the following section we discuss the suitability of lead compounds with biologically relevant functional groups $(-S$, $-\mathrm{N},-\mathrm{NO}_{3},-\mathrm{PO}_{4}$, and $\left.-\mathrm{COO}\right)$. Processes connected to sulfur bonding (e.g., proteins) cannot be represented well by lead sulfide $(\mathrm{PbS})$ since it is an insoluble inorganic salt with sulfur in the first and lead in the second coordination, whereas Scontaining proteins have hydrocarbon chains beyond the sulfur coordination. Magyar and co-workers ${ }^{34}$ investigated several $\mathrm{Pb}$ peptide complexes which model the lead exchange with zinc in ALAD (delta-aminolevulinic acid dehydratase). This study showed that lead-containing organic sulfur compounds result in quite different XANES spectra compared to lead sulfide. Using EXAFS the $\mathrm{Pb}-\mathrm{S}$ bonding distance in the peptides was determined to be $2.6 \AA$ but is $2.9 \AA$ in $\mathrm{PbS}$. The $\mathrm{Pb} \mathrm{L} \mathrm{L}_{3}$-XANES spectrum of hexadecyl lead mercaptide is very similar to one of the lead peptides measured by Magyar and co-workers ${ }^{34}$ (not shown). This means that hexadecyl lead mercaptide is suitable to model the organic $\mathrm{Pb}-\mathrm{S}$ environment. The compound used for modeling a $\mathrm{Pb}-\mathrm{N}$ environment similar to the one in the heme molecule, phthalocyanine lead, was commercially available. Lead nitrate $\left(\mathrm{Pb}-\mathrm{O}_{3} \mathrm{~N}\right)$ is a soluble compound and dissolves in water. The XANES spectra of the solid and the dissolved form of lead nitrate are very different (cf. Figure 1). Phosphates are important in plants but lead phosphates such as chloropyromorphite are the most insoluble lead compounds. ${ }^{35}$ Indeed, precipitation of chloropyromorphite in plants as a response to lead contamination has been reported. ${ }^{11}$ Hence, chloropyromorphite was synthesized because it was not commercially available, and was included in our analyses. Lead citrate tri hydrate, lead(II) acetate, and lead(IV) acetate were selected for the modeling of COO-groups. However, lead citrate tri hydrate was not included in the analysis for reasons presented above.

All metabolic processes in living organisms run on the basis of water and $\mathrm{Pb}^{2+}$ ions are likely the lead species taken up by plants from the soil solution. ${ }^{9}$ For this reason we prepared different aqueous lead reference samples: low ionic strength with high $\mathrm{pH}$ (around 6), high ionic strength with low $\mathrm{pH}$ 
(3.4), and high $\mathrm{pH}(7-8)$ (cf. Figure 1) that were used in mineralogical studies before. ${ }^{18,19,30}$ The XANES spectra of these solution samples show the same edge and peak positions as well as general shape as was reported by Strawn and Sparks for their mineral adsorption studies. ${ }^{19}$

$\mathrm{Pb}$ Speciation in Plant Samples. XANES was used to determine the $\mathrm{Pb}$ speciation in different plant tissues. Figure 2

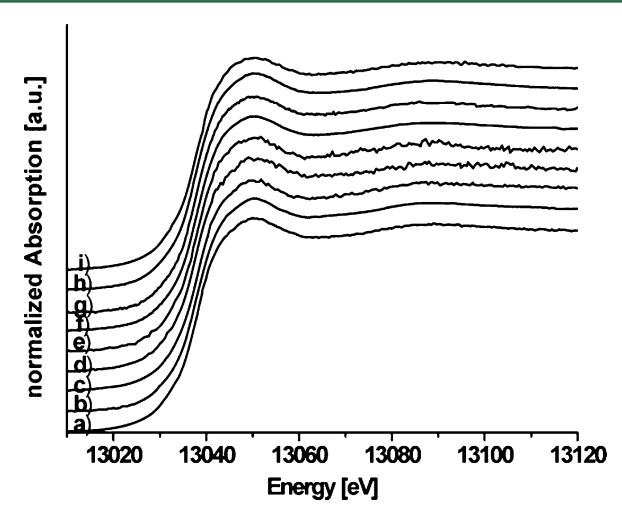

Figure 2. $\mathrm{Pb} \mathrm{L}_{3}$-XANES spectra of dried plant samples (winter collection): (a) Cladonia portentosa, (b) A. pratensis root, (c) A. pratensis leaf, (d) F. ovina root, (e) F. ovina leaf, (f) S. vulgaris root, (g) S. vulgaris stem, (h) A. maritima root, (i) A. maritima leaf. The spectra are shifted for clarity.

shows the $\mathrm{Pb} \mathrm{L}_{3}$-XANES spectra taken from the different plant parts from the winter season. Notably, all the spectra are very similar now indicating similar uptake and storage mechanisms. A comparison of spectra of plant parts from the different collections in winter and summer on the basis of the $\Delta$ RMS method shows that all plant samples excluding the fresh roots of $F$. ovina are not distinguishable from each other. The calculated difference $(\Delta \mathrm{RMS}=0.018)$ between fresh $S$. vulgaris roots and fresh $F$. ovina roots is just above the uncertainty limit (see above) and thus is detectable. SI Figure S2 shows the XANES spectra of fresh roots of $S$. vulgaris and $F$. ovina compared to each other.

For our LCF analysis we only used the spectra of fresh $S$. vulgaris roots and fresh F. ovina roots because the spectra of the other plant samples were all indistinguishable to the spectrum of fresh $S$. vulgaris roots. The $\mathrm{Pb} \mathrm{L}_{3}$-XANES spectra of fresh $S$. vulgaris roots and fresh $F$. ovina roots have the same $E_{0}$ position of $13037.7 \mathrm{eV}$ determined as the energy value of the maximum of the first derivative. Other characteristics are quite different: WL maximum of 13048.8 and $13050.5 \mathrm{eV}(+11 \mathrm{eV}$ and $\approx+13$ $\mathrm{eV}$ in relation to $\left.E_{0}\right)$ and maximum of the first shape resonance of 13082.9 and $13092.9 \mathrm{eV}\left(+45\right.$ and $+55 \mathrm{eV}$ in relation to $\left.E_{0}\right)$, respectively, for fresh $S$. vulgaris roots and fresh F. ovina roots. In order to understand the biology of the lead uptake in plants we checked the existence of $\mathrm{Pb}$ bonding to biologically relevant functional groups by applying linear combination fitting. We only used combinations of two lead references out of 23 to fit the plant samples because of the limitations of the method mentioned earlier.

The overview of the statistically significant fits is displayed in SI Tables S3 and S4 for the plant samples of fresh S. vulgaris roots and fresh $F$. ovina roots, respectively. As shown in SI Table S3, several fits have the same quality as $\chi_{i}^{2} / \chi_{\text {ref }}^{2} \leq 2$. The spectra of the solution with $\mathrm{Pb}^{2+}(\mathrm{aq})$ with high $\mathrm{pH}$ and low ionic strength and lead chromate are very similar but the $\Delta$ RMS value $(0.016)$ is above the uncertainty limit for transmission samples (cf. Figure 1). For this reason lead chromate was included in the fitting procedure and fit no. 1 shows that a pure oxygen environment for $\mathrm{Pb}$ inside the roots is very likely even though lead chromate is unlikely the correct environment. The data show that the major compound for the spectrum of fresh S. vulgaris roots, with more than $50 \%$, is $\mathrm{Pb}^{2+}$ (aq) with high $\mathrm{pH}$ and low ionic strength because the LC fits (no. 2-10) with this compound have the same level of quality (SI Table S3). A second/minor compound could be the solution with $\mathrm{Pb}_{4}(\mathrm{OH})_{4}{ }^{4+}$ (aq) (high ionic strength and high $\mathrm{pH}$ ) with $30 \%$ (fit no. 8) or lead acetate (fit no. 4). As an example fit no. 8 is displayed in SI Figure S3 for fresh S. vulgaris roots. Other minor contribution are mostly $\mathrm{Pb}-\mathrm{O}$ containing reference compounds which supports the above statement for pure $\mathrm{Pb}-\mathrm{O}$ environment. For F. ovina roots only fits no. 1-10 are relevant because they have the same major compound and level of quality (cf. SI Table S4). The major compound is the solution with $\mathrm{Pb}_{4}(\mathrm{OH})_{4}{ }^{4+}$ (aq) (high ionic strength and high $\mathrm{pH}$ ) with more than $78 \%$. Here, no second compound is significant within our fitting procedure. Fit no. 9 (cf. SI Figure S4), displays the good agreement of the fitting process. Only fit no. 11 is different. However, both reference compounds $\mathrm{Pb}^{2+}(\mathrm{aq})$ with low ionic strength and high $\mathrm{pH}$ and lead silicate confirm the predominant lead oxygen environment.

In all the fits the $\mathrm{Pb}-\mathrm{S}$ model compound hexadecyl lead mercaptide always had a fraction less than $15 \%$ which concludes lead bonding to proteins/peptides via sulfur is very unlikely to be a response of the plant to the lead uptake.This agrees with the majority of previous reports. ${ }^{8,9,11-17}$ It is possible though that lead binds to sulfur with less than these $15 \%$, but as we stated in a previous section, but this cannot be confirmed by LCF. Binding to nitrogen $(\mathrm{Pb}-\mathrm{N})$ is also very unlikely for the same reason as above for the $\mathrm{Pb}-\mathrm{S}$ bonding. Precipitation of lead phosphate in the form of chloropyromorphite is also not likely because no LC fit with this compound has $\chi_{i}^{2} / \chi_{\text {ref }}^{2} \leq 2$. This is contradictory to the results given by Cotter-Howells and co-workers ${ }^{11}$ where chloropyromorphite was determined to be the major compound. However, the effect of the nutrition solution has to be considered. Previous studies that used nutrition solutions or fertilizer with $\mathrm{PO}_{4}$, because it is classified as essential, determined chloropyromorphite as the lead speciation in plants. ${ }^{11,36}$ Whereas, studies that did not use P-containing fertilizer or nutrition solution did not find chloropyromorphite as the lead speciation in plants or plant material. ${ }^{8-10,13}$

X-ray Tomography. Images taken at $12.5 \mathrm{keV}$ and 13.5 $\mathrm{keV}$ (not shown) do not appear to vary significantly, but the difference of these images, obtained by subtracting the absorption values for each individual voxel in space by the slice reconstructions, indicated the presence of $\mathrm{Pb}$ (Figure 3 ). The average $\mathrm{Pb}$ vol\% in one voxel $\left(2.5^{3} \mu \mathrm{m}^{3}\right)$ is estimated to 0.056 vol\%. The distribution of $\mathrm{Pb}$ is highest in the epidermis, with lower levels being present in the central, vascular tissues. Thus, this element specific X-ray tomography supports the hypothesis that lead uptake is mainly limited to the epidermis of the roots. A very low concentration of lead is evident in the central portion of the root that contains the vascular tissues, xylem and phloem. This indicates that only a very small amount of lead (about 16\%) is transported within the plant roots (cf. SI Table S2) to the upper parts of the plant. This is in agreement with the literature. ${ }^{36}$ 


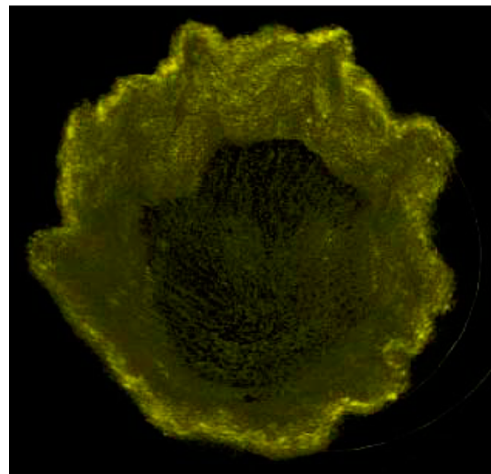

Figure 3. 3-D view of the difference image of the X-ray tomography measurement of $S$. vulgaris roots (summer - dried) at $\mathrm{Pb} \mathrm{L}_{3}$-edge. Data volume size is $2.4 \times 2.4 \times 2.4 \mathrm{~mm}^{3}$ with $2.5 \mu \mathrm{m}$ spatial resolution. High concentrations of $\mathrm{Pb}$ are shown in bright yellow.

\section{DISCUSSION}

We analyzed the $\mathrm{Pb} \mathrm{L}_{3}$-XANES spectra regarding their sensitivity to differences in chemical environments and regarding the detection limit in the $\mathrm{Pb} \mathrm{L}_{3}$-XANES spectra $\mathrm{LCF}$ process. Even though $\mathrm{Pb} \mathrm{L}_{3}$-XANES spectra lack a significant fine structure, differences in the chemical environment around the $\mathrm{Pb}$ atom up to the third coordination shell can be distinguished using the $\triangle \mathrm{RMS}$ or the LCF method. For this study we used a variety of commercially available lead compounds in powder form as well as synthesized lead compounds as powders, but also aqueous solutions with various $\mathrm{pH}$ values. This thorough investigation strongly supports that powder compounds are not suited to completely describe biological systems. Also, compounds such as lead citrate trihydrate and $\mathrm{Pb}^{2+}$ (aq) with $\mathrm{pH} 5.5$ and low ionic strength cannot be distinguished. Both compounds can be used interchangeably.

Previously, the chemical environment of $\mathrm{Pb}$ inside plants was mainly determined as carboxylic acid..$^{8-10,12-17}$ However, lead(II) acetate or lead(IV) acetate were not determined as major compounds in the LC fitting procedure. Instead, $\mathrm{Pb}$ ions in solutions were predominantly determined as the major compounds. Other studies have shown that inside roots lead is found close to cell walls. ${ }^{36}$ The cell wall is composed of polysaccharides such as pectines, hemicelluloses, cellulose, and proteins where pectines form the matrix and the cellulose chains, interconnected through $\mathrm{Mg}^{2+}$ and $\mathrm{Ca}^{2+}$ and crosslinked; make up the basic structure. ${ }^{37} \mathrm{Ca}$ - or $\mathrm{Mg}$-ions can be exchanged for $\mathrm{Pb}^{2+}{ }^{17}$ This exchange mechanism seems to be supported by the data for $\mathrm{Mg}$ presented in SI Table S2 since it shows consistently less $\mathrm{Mg}$ in the roots of the plants. For Ca only, in S. vulgaris and A. pratensis, less is present in the roots. However, no control samples (without $\mathrm{Pb}$ ) where available to further support this hypothesis.

The high similarity of the $\mathrm{Pb} \mathrm{L}_{3}$-XANES spectra of plants from Keldenich with the spectra from $\mathrm{Pb}-\mathrm{O}$ coordinated compounds, especially in aqueous solution, supports the following hypothesis: lead is sorbed on surfaces inside the plants. The cell wall is still the most likely place for the sorption of lead. The potential of lead adsorption by dried biomass such as alfalfa, hop, peat, and fungi was investigated previously. ${ }^{14,16,17,38}$ However, these XAS experiments did not include the complete set of solutions as used here. Also, sorption was not discussed for living plants. Our study reveals that also in living plants sorption of $\mathrm{Pb}$ is the main process for storage. For high $\mathrm{pH}$ and low ionic strength the aqueous lead solutions consist of hydrated $\mathrm{Pb}^{2+}$ ions where nine oxygen atoms surround $\mathrm{a} \mathrm{Pb}$ atom in outer-sphere complexation at a $\mathrm{Pb}-\mathrm{O}$ distance of about $2.5 \AA \AA^{19}$ At high ionic strength and high $\mathrm{pH}$ the $\mathrm{Pb}$ atoms become hydrolyzed and are complexed in inner-spheres with three oxygens at a $\mathrm{Pb}-\mathrm{O}$ distance of about 2.3 $\AA$. At this bond distance covalent bonds $(\mathrm{Pb}-\mathrm{O})$ are formed. ${ }^{19}$ Following the definitions of sorption processes, outer-sphere complexation can be correlated with IonExchange and inner-sphere complexation can be correlated with chemisorption. ${ }^{39}$ Ion-exchange of $\mathrm{Pb}^{2+}$ with $\mathrm{Mg}^{2+}$ or $\mathrm{Ca}^{2+}$ is therefore likely. Sari and co-workers ${ }^{40}$ who reported equilibrium studies of the biosorption of $\mathrm{Pb}$ on biomass also indicate that ion exchange is the main mechanism for $\mathrm{Pb}(\mathrm{II})$ to bind to biomass. This sorption picture is "captured" in the TOC art where only the cellulose is depicted as a framework.

Sorption experiments explain the very low mobility of lead in soil because sorption on hydrous oxides, clay minerals, and other surfaces was observed. ${ }^{18,19,30} \mathrm{~Pb}$ shows to have the highest adsorption uptake rates compared to other ions such as $\mathrm{Cu}^{2+}$ and $\mathrm{Zn}^{2+}$ for many different ion exchange materials such as functionalized cellulose, zeolites and resins. ${ }^{41-43}$

Focusing on sorption only, LCF analysis of all plant samples was attempted (cf. SI Table S5). For fresh plant tissues the compositions of the LC fittings vary from about $70 \%$ outersphere and $30 \%$ inner- sphere complexation (most samples) to about 50/50 (roots of $A$. maritima), but also 30/70 (leaves of $A$. maritima and roots of $A$. pratensis). For all dried plant samples and the lichen, a composition of about 50/50 was found. Innersphere coordination dominated (100\%) only for the roots of $F$. ovina. Sorption can explain why fresh and dried plant samples have similar XANES spectra that are not distinguishable with the sensitivity limits given for the $\Delta \mathrm{RMS}$ method. Compared to other metals (metalloids) like arsenic where the drying process results in a significant change in the binding ligand from sulfur in glutathione (in green plant samples) to oxygen in arsenide (in dried plant samples) the differences in the lead speciation in the plants from the Eifel due to drying are not significant. ${ }^{44-47}$ However, the differences in the LCF fractions show that drying quite likely affects the coordination of $\mathrm{Pb}$ inside the plants and indicating chelation in a similar fashion as observed for arsenic.

The differences in the chemical environment of lead in $S$. vulgaris and $F$. ovina may be explained by the following observation. For plants like A. maritima or S. vulgaris the roots are thick and long (cf. SI Figure S5). These roots have a large surface area and many layers of epidermis tissue. Whereas, for F. ovina and A. pratensis, the roots are very thin (cf. SI Figure S7, S8) and do not have a large surface area and not many layers of epidermis tissue. Similar lead concentrations in the soil for A. maritima, $S$. vulgaris, and $F$. ovina were reported previously. ${ }^{29}$ So, the roots of all these plants are confronted with a high concentration of lead. But since the roots of F. ovina have a much larger surface to volume ratio compared to $S$. vulgaris the lead concentration at the epidermis of the roots of F. ovina is significantly higher and thus, the ionic strength is much higher for F. ovina than for S. vulgaris. The property responsible for the effect of more inner sphere coordination in F. ovina roots is ionic strength.

The quality of the LC fits in SI Table S5 is good for most of the plant samples. Only for the fresh leaves of $S$. vulgaris the fitting quality is not acceptable. This means that (a) sorption is not the main process in $S$. vulgaris leaves and (b) a reference compound is still missing. This missing compound could be 
$\mathrm{Pb}$-EDTA (Ethylenediaminetetraacetic acid lead). Chelation of $\mathrm{Pb}$ with EDTA was reported previously. ${ }^{13}$ It is possible that in $S$. vulgaris plants $\mathrm{Pb}$ is chelated with EDTA and transported into the leaves.

Based on these results we propose the following process for lead uptake into plants: Lead enters the root within the outer apoplast from the soil solution as $\mathrm{Pb}^{2+}$ (aq) or lead hydrolysis complex $\mathrm{Pb}_{4}(\mathrm{OH})_{4}{ }^{4+}$ (aq) depending on $\mathrm{pH}$ and lead concentration in the soil solution. The element specific X-ray tomography confirmed that lead was found mainly in the epidermis of the root with little present in the central regions of the root. The more $\mathrm{Pb}$ is coordinated in inner sphere complexation, the less $\mathrm{Pb}$ can be taken up into shoots. This is consistent with the concentration data in SI Table S2: for F. ovina much less $\mathrm{Pb}$ is translocated into upper parts than for $S$. vulgaris. Summarizing, sorption as the storage mechanism of $\mathrm{Pb}$ in plants explains the similarity of the XANES spectra as well as the differences in absolute concentrations in roots and shoots.

\section{ASSOCIATED CONTENT}

\section{S Supporting Information}

Additional information can be found in the Supporting Information. The material is available free of charge via the Internet at http://pubs.acs.org/.

\section{AUTHOR INFORMATION}

\section{Corresponding Author}

*Phone: 225.578.9375; fax: 225.578.6954; e-mail: lbovenkamp@lsu.edu.

\section{Notes}

The authors declare no competing financial interest.

\section{ACKNOWLEDGMENTS}

We thank ANKA-ISS and CAMD for provision of beam time as well as the staff of INE, and X-ray Tomography beamlines for their support. We also thank CSSR Kumar for insightful discussions and support with the chemical synthesis. Finally, we thank the reviewers for invaluable comments.

\section{REFERENCES}

(1) Casas, J. S., Sordo, J., Eds. Lead - Chemistry, Analytical Aspects, Environmental Impact and Health Effects; Elsevier: Amsterdam, 2006.

(2) Peer, W. A., Baxter, I. R., Richards, E. L., Freeman, J. L., Murphy, A. S. Phytoremediation and hyperaccumulator plants. In Molecular Biology of Metal Homeostasis and Detoxification, Series: Topics in Current Genetics; Tamás, M. J., Martinoia, E., Eds.; Springer: Berlin, 2006; Vol. 14.

(3) Clemens, S.; Palmgren, M. G.; Krämer, U. A. A long way ahead: Understanding and engineering plant metal accumulation. Trends Plant Sci. 2002, 7 (7), 309-315, DOI: 10.1016/S1360-1385(02)02295-1.

(4) Peralta-Videa, J. R.; Lopez, M. L.; Narayan, M.; Saupe, G.; Gardea-Torresdey, J. The biochemistry of environmental heavy metal uptake by plants: Implications for the food chain. Int. J. Biochem. Cell Biol. 2009, 41, 1665-1677, DOI: 10.1016/j.biocel.2009.03.005.

(5) Schumacher, W. Flora und Vegetation der Sötenicher Kalkmulde (Eifel): Decheniana Beihefte 197719.

(6) Brown, G. Vegetationsökologische Untersuchungen im Bleierzabbaugebiet der Mechernicher Triasbucht/Eifel. Angew. Botanik 1990, 64, 457-488.

(7) Gardea-Torresdey, J. L.; Peralta-Videa, J. R; de la Rosa, G.; Parsons, J. G. Phytoremediation of heavy metals and study of the metal coordination by X-ray absorption spectroscopy. Coord. Chem. Rev. 2005, 249, 1979-1810, DOI: 10.1016/j.ccr.2005.01.001.
(8) Lopez, M.; Peralta-Videa, J. R.; Parsons, J. G.; Gardea-Torresdey, J. L. Gibberellic acid, kinetin, and the mixture indole-3-acetic acidkinetin assisted with EDTA-induced lead hyperaccumulation in alfalfa plants. Environ. Sci. Technol. 2007, 41, 8165-8170, DOI: 10.1021/ es0714080.

(9) Wang, H.; Shan, X.; Liu, T.; Xie, Y.; Wen, B.; Zhang, S.; Han, F.; van Genuchten, M. T. Organic acids enhance the uptake of lead by wheat roots. Planta 2006, 225 (6), 1483-1494, DOI: 10.1007/ s00425-006-0433-7.

(10) Sharma, N. C.; Gardea-Torresdey, J. L.; Parsons, J.; Sahi, S. V. Chemical speciation and cellular deposition of lead in Sesbania drummondii. Environ. Toxicol. Chem. 2004, 23, 2068-2073, DOI: $10.1897 / 03-540$.

(11) Cotter-Howells, J. D.; Champness, P. E.; Charnock, J. M. Mineralogy of $\mathrm{Pb}-\mathrm{P}$ grains in the roots of Argostis capillaris L. by ATEM and EXAFS. Mineral. Mag. 1999, 63 (6), 777-789.

(12) Tian, S. K.; Lu, L. L.; Yang, X. E.; Brown, P. H.; Webb, S. L.; $\mathrm{Du}, \mathrm{Y}$. H. Spatial imaging and speciation of lead in the accumulator plant Sedum alfredii by microscopically focused synchrotron X-ray investigation. Environ. Sci. Technol. 2010, 44, 5920 DOI: 10.1021/ es903921t.

(13) Tian, S. K.; Lu, L. L.; Yang, X. E.; Huang, H. G.; Brown, P.; Labavitch, J.; Liao, H. B.; He, Z. L. The impact of EDTA on lead distribution and speciation in the accumulator Sedum alfredii by synchrotron X-ray investigation. Environ. Pollut. 2011, 159 (3), 782788, DOI: $10.1016 /$ j.envpol.2010.11.020.

(14) Gardea-Torresdey, J. L.; Hejazi, M.; Tiemann, K.; Parsons, J. G.; Duarte-Gardea, M. Henning, Use of hop (Humulus lupulus) agricultural by-products for the reduction of aqueous lead(II) environmental health hazards J. J. Hazard. Mater. B 2002, 91, 95112, DOI: 10.1016/S0304-3894(01)00363-6.

(15) De la Rosa, G.; Peralta-Videa, J. R.; Parsons, J. G.; GardeaTorresdey, J. L. Using X-ray absorption spectroscopy to study the speciation and coordination of lead binding to humic materials. Spectroscopy 2005, 20 (7), 24-30.

(16) Tiemann, K. J.; Gamez, G.; Dokken, K.; Parsons, J. G.; GardeaTorresdey, J. L. Chemical modification and X-ray absorption studies for lead (II) binding in Medicago sativa (alfalfa) biomass. Microchem J 2002, 71, 287-293.

(17) Qin, F.; Wen, B.; Shan, X.; Xie, Y.; Liu, T.; Zhang, S. Mechanisms of competitive adsorption of $\mathrm{Pb}, \mathrm{Cu}$, and $\mathrm{Cd}$ on peat. Environ. Pollut. 2006, 144, 669-680, DOI: 10.1016/j.envpol.2005.12.036.

(18) Rouff, A. A.; Elzinga, E. J.; Reeder, R. J.; Fisher, N. S. X-ray absorption spectroscopic evidence for the formation of $\mathrm{Pb}$ (II) innersphere adsorption complexes and precipitates at the calcite-water interface. Environ. Sci. Technol. 2004, 38, 1700-1707, DOI: 10.1021/ es0345625.

(19) Strawn, D. G.; Sparks, D. L. The Use of XAFS to distinguish between inner- and outer-sphere lead adsorption complexes on montmorillonite. J. Colloid Interface Sci. 1999, 216 (2), 257-269.

(20) Baes, C. F.Jr., Mesmer, R. E. The Hydrolysis of Cations; John Wiley \& Sons: New York, 1976.

(21) Dr. Böhling Laboratory of analytical chemistry, private communication, Bonn, Germany. 2008.

(22) Ham, K.; Jin, H.; Butler, L. G.; Kurtz, R. L. A microtomography beamline at the Louisiana State University Center for Advanced Microstructures and Devices Synchrotron. Rev. Sci. Instrum. 2002, 73 (3), 1521-3.

(23) Ham, K.; Barnett, H. A.; Ogunbakin, T.; Homberger, D. G.; Bragulla, H. H.; Matthews, K. L. Imaging tissue structures: Assessment of absorption and phase-contrast X-ray tomography imaging at 2-nd and 3-rd generation synchrotrons. Proc. SPIE 2006, 6318, 631822.

(24) Ham, K.; Jin, H.; Al-Raoush, R. I.; Xie, X. G.; Willson, C. S.; Byerly, G. R. Three-dimensional chemical analysis with synchrotron tomography at multiple X-ray energies: Brominated aromatic flame retardant and antimony oxide in polystyrene. Chem. Mater. 2004, 16, $4032-4042$. 
(25) Ravel, B.; Newville, M. ATHENA, ARTEMIS, HEPHAESTUS: Data analysis for X-ray absorption spectroscopy using IFEFFIT. J. Synchrotron Radiat. 2005, 12, 537-541, DOI: 10.1107/ S0909049505012719.

(26) Eltrop, L.; Brown, G.; Joachim, O.; Brinkmann, K. Lead tolerance of Betula and Salix in the mining area of Mechernich/ Germany. Plant Soil 1991, 131, 275-285, DOI: 10.1007/BF00009459.

(27) Päivöke, A. E.A. Responses of Pisum sativum to soil arsenate, lead and zinc: A greenhouse study of mineral elements, phytase activity, ATP and chlorophylls, Dissertation, University of Helsinki, Finland. 2003.

(28) Zaier, H.; Ghnaya, T.; Lakhdar, A.; Baioui, R.; Ghabriche, R.; Mnasri, M.; Sghair, S.; Lutts, S.; Abdelly, C. Comparative study of $\mathrm{Pb}$ phytoextraction potential in Sesuvium portulacastrum and Brassica juncea: Tolerance and accumulation. J. Hazard. Mater. 2010, 183 (13), 609-615, DOI: 10.1016/j.jhazmat.2010.07.068.

(29) Brown, G. Soil factors affecting patchiness in community composition of heavy metal contaminated areas of Western Europe. Vegetatio 1994, 115, 77-90.

(30) Bargar; Bargar, J. R.; Brown, G. E., Jr.; Parks, G. A.; et al. Surface complexation of $\mathrm{Pb}(\mathrm{II})$ at oxide-water interfaces. I. XAFS and bondvalence determination of mononuclear and polynuclear $\mathrm{Pb}(\mathrm{II})$ sorption products on aluminum oxides. Geochim. Cosmochim. Acta 1997a, 61, 2617-2637.

(31) Bovenkamp, G. L. Prange, A. Roy, A. Schumacher, W. Hormes, J. Proceedings 14th International Conference on X-Ray Absorption Fine Structure (XAFS14) J. Phys.: Conf. Ser. 2009190 (012190), DOI: 10.1088/1742-6596/190/1/012190.

(32) Kelly, S. D., Hesterberg, D., and Ravel, B. Analysis of soils and minerals using X-ray absorption spectroscopy. In. Methods of Soil Analysis. Part 5. Mineralogical Methods; Ulery, A. L., Drees, R., Eds.; Soil Sci Soc Am: Madison, WI. 2008; pp 387-464.

(33) Huggins, F. E.; Kim, D.-J.; Dunn, B. C.; Eyring, E. M.; Huffman, G. P. An evaluation of least-squares fitting methods in XAFS spectroscopy: Iron-based SBA-15 catalyst formulations. Spectrochim. Acta A 2009, 72 (5), 975-983, DOI: 10.1016/j.saa.2008.12.026.

(34) Magyar, J. S.; Weng, T. C.; Stern, M. C.; Dye, D. F.; Rous, B. W.; Payne, J. C.; Bridgewater, B. M.; Mijovilovich, A.; Parkin, G.; Zaleski, J. M.; Penner-Hahn, J. E.; Godwin, H. A. Reexamination of lead(II) coordination preferences in sulfur-rich sites: Implications for a critical mechanism of lead poisoning. J. Am. Chem. Soc. 2005, 127, 9495-9505, DOI: $10.1021 /$ ja0424530.

(35) Morel, F. M. M., Hering, J. G. Principles and Applications of Aquatic Chemistry; John Wiley \& Sons: New York. 1993.

(36) Kopittke, P. M.; Asher, C. J.; Pax, F.; Blamey, C.; Auchterblonie, G. J.; Guo, Y.; Menzes, W. Localization and Chemical Speciation of $\mathrm{Pb}$ in Roots of Signal grass (Brachiaria decumbens) and Rhodes Grass (Chloris gayana). Environ. Sci. Technol. 2008, 42, 4595-4599, DOI: $10.1021 /$ es702627c.

(37) Kindl, H. Biochemie the Pflanzen; Springer: Berlin, 1984.

(38) Sarret, G.; Manceau, A.; Spadini, L.; Roux, J. C.; Hazemann, J. L.; Soldo, Y.; Eybert-Bérard, L.; Menthonnex, J. J. Structural determination of $\mathrm{Zn}$ and $\mathrm{Pb}$ binding sites in Penicillium chrysogenum cell walls by EXAFS spectroscopy. Environ. Sci. Technol. 1998, 32, 1648-1655, DOI: 10.1021 /es9709684.

(39) Inglezakis, V. J., Poulopoulos, S. G. Adsorption, Ion Exchange and Catalysis; Elsevier: Amsterdam, 2006.

(40) Sari, A.; Tuzen, M. Kinetic and equilibrium studies of biosorption of $\mathrm{Pb}(\mathrm{II})$ and $\mathrm{Cd}(\mathrm{II})$ from aqueous solution by macrofungus (Amanita rubescens) biomass. J. Hazard. Mater. 2009, 164 (2), 1004-1011, DOI: 10.1016/j.jhazmat.2008.09.002.

(41) O'Connell, D. W.; Birkinshaw, C.; O’Dwyer, T. F. Heavy metal adsorbents prepared from the modification of cellulose: A review. Bioresour. Technol. 2008, 99, 6709-6724, DOI: 10.1016/j.biortech.2008.01.036.

(42) Calvo, B.; Canoira, L.; Morante, F.; Martinez-Bedia, J. M.; Vinagre, C.; Garcia-Gonzalez, J. E.; Elsen, J.; Alcantara, R. Continuous elimination of $\mathrm{Pb}^{2+}, \mathrm{Cu}^{2+}, \mathrm{Zn}^{2+}, \mathrm{H}^{+}$and $\mathrm{NH}_{4}{ }^{+}$from acidic waters by ionic exchange on natural zeolites. J. Hazard Mater. 2009, 166, 619627, DOI: $10.1016 /$ j.jhazmat.2008.11.087.

(43) Demirbas, A.; Pehlivan, E.; Gode, F.; Altun, T.; Arslan, G. Adsorption of $\mathrm{Cu}(\mathrm{II}), \mathrm{Zn}(\mathrm{II}), \mathrm{Ni}(\mathrm{II}), \mathrm{Pb}(\mathrm{II})$, and $\mathrm{Cd}(\mathrm{II})$ from aqueous solution on Amberlite IR-120 synthetic resin. J. Colloid Interface Sci. 2005, 282, 20-25, DOI: 10.1016/j.jcis.2004.08.147.

(44) Bovenkamp, G. L., Röntgenabsorptionsspektroskopie zur Charakterisierung von Arsen und Blei in kontaminierten Pflanzen. DiplomThesis, University of Bonn: Bonn, Germany, 2008 (unpublished).

(45) Smith, P. G., Arsenic Biotransformation in Terrestrial Organisms. Ph.D. dissertation, Queen's University: Kingston, Ontario, Canada, 2007.

(46) Pickering, I. J.; Gumaelius, L.; Harris, H. H.; Prince, R. C.; Hirsch, G.; Banks, J. A.; Salt, D. E.; George, G. N. Localizing the biochemical transformations of arsenate in a hyperaccumulating fern. Environ. Sci. Technol. 2006, 40, 5010-5014, DOI: 10.1021/es052559a.

(47) Pickering, I. J.; Prince, R. C.; George, M. J.; Smith, R. D.; George, G. N.; Salt, D. E. Reduction and coordination of arsenic in indian mustard 1. Plant Physiol. 2000, 122, 1171-1177. 